\title{
The development of electrolytes for intermediate temperature solid oxide fuel cells
}

\author{
E. Yu. Pikalova ${ }^{1,2}$, V. G. Bamburov ${ }^{2,3}$, I. V. Rukavishnikova ${ }^{2}$, \\ A. K. Demin ${ }^{1} \&$ A. A. Kolchugin ${ }^{1}$ \\ ${ }^{1}$ Institute of High Temperature Electrochemistry, \\ Russian Academy of Sciences, Russia \\ ${ }^{2}$ Department of Environmental Economics, \\ Ural Federal University, Russia \\ ${ }^{3}$ Institute of Solid State Chemistry, Russian Academy of Sciences, Russia
}

\begin{abstract}
This report describes a number of experimental studies on the solid state electrolytes for intermediate temperature solid oxide fuel cells (IT-SOFCs): $\mathrm{Ce}_{1-\mathrm{x}} \mathrm{Ln}_{\mathrm{x}} \mathrm{O}_{2-\delta}(\mathrm{Ln}=\mathrm{La}, \mathrm{Nd}, \mathrm{Sm}, \mathrm{Eu}, \mathrm{Gd}$, Dy, Ho, Er, Yb), some multicomponent systems $\mathrm{Ce}_{1-\mathrm{x}} \mathrm{Ln}_{\mathrm{x} / 2} \mathrm{Ln}^{\prime}{ }_{\mathrm{x} / 2} \mathrm{O}_{2-\delta}\left(\mathrm{x}=0-0.20 ; \mathrm{Ln}=\mathrm{Sm}, \mathrm{La}, \mathrm{Gd}\right.$ and $\mathrm{Ln}^{\prime}=\mathrm{Dy}$, $\mathrm{Nd}$, Y), some systems with simultaneous doping by rare earth and alkali earth elements $\mathrm{Ce}_{0.8}\left(\mathrm{Sm}_{1-\mathrm{x}} \mathrm{M}_{\mathrm{x}}\right)_{0.2} \mathrm{O}_{2-\delta}(\mathrm{M}=\mathrm{Ca}, \mathrm{Sr} ; \mathrm{x}=0.0-1.0)$ and $\mathrm{Ce}_{0.8}\left(\mathrm{Sm}_{1-\mathrm{x}-\mathrm{y}} \mathrm{Ba}_{\mathrm{y}} \mathrm{M}_{\mathrm{x}}\right)_{0.2} \mathrm{O}_{2-\delta}(\mathrm{M}=\mathrm{Ca}, \mathrm{Sr} ; \mathrm{x}=0,0.15,0.20 ; \mathrm{y}=0.05,0.1)$. Two important aspects are emphasized: the effect of different dopants' ionic radius and concentration on the electrical properties of $\mathrm{CeO}_{2}$ based solid solutions and the influence of the method of preparation on the structural properties of ceria ceramics and the electrochemical performance of single SOFCs on their base. To describe the electrolytic properties of solid electrolytes the notation of the electrolytic domain boundary (EDB) - the critical oxygen partial pressure $\left(P_{O_{2}}^{*}\right)$ at which the values of the electronic and ionic components of conductivity are equal, were calculated and presented. The interpretation of these data will lead to a better understanding of, subsequent improvements to and ultimately, the commercialization of IT-SOFCs in Russia.
\end{abstract}

Keywords: alternative energy, SOFC, solid state electrolytes, oxygen conductivity, $\mathrm{CeO}_{2}$, electrolytic domain boundary. 


\section{Introduction}

Nowadays economic and environmental factors define global changes in energy production and distribution market. Approximately $94 \%$ of $\mathrm{CO}_{2}$ emissions in Europe are attributable to the energy sector as a whole; oil consumption accounts for $50 \%$ of $\mathrm{CO}_{2}$ emissions in $\mathrm{EU}$, natural gas for $22 \%$ and coal for $28 \%$, respectively. In the Russian Federation the energy sector is also a major source of pollution. It accounts for over 50 percent of emissions of pollutants into the atmosphere and over 20 percent of waste water discharged into surface watercourses, as well as more than 70 percent of total greenhouse gas emissions. The unpredictability of supply and strong dependence on politically unstable countries, environmental and global warming issues and adherence to the new European legislation related to the deregulation of the energy market all contribute to the introduction of new technologies in the energy field [1-4].

New energy technologies can contribute to the security of supply objectives in several ways, by reducing fuel demand through end-use energy efficiency measures, by utilizing diversified fuel sources, e.g. enabling fuel switching, fuel flexibility and by utilizing renewable energy sources. In the ongoing search for alternative and environmentally friendly power generation facilities, the Solid Oxide Fuel Cells (SOFCs) have generated much interest as a potential economical, clean and efficient candidate for the decentralised generation of heat and power (Table 1).

Table 1: Comparison of the environmental impact of different energy production systems.

\begin{tabular}{|c|c|c|c|c|c|}
\hline \multirow{2}{*}{$\begin{array}{c}\text { Type of power plant and } \\
\text { used fuel }\end{array}$} & \multicolumn{5}{|c|}{$\begin{array}{c}\text { Concentration of hazardous components in } \\
\text { emissions, } \mathrm{mg} / \mathrm{m}^{3}\end{array}$} \\
\cline { 2 - 6 } & $\mathrm{SO}_{\mathrm{x}}$ & $\mathrm{NO}_{\mathrm{x}}$ & $\mathrm{CO}$ & $\begin{array}{c}\text { Hydro- } \\
\text { carbons }\end{array}$ & $\begin{array}{c}\text { Solid } \\
\text { particles }\end{array}$ \\
\hline $\begin{array}{c}\text { New heat electropower } \\
\text { station (coal) }\end{array}$ & 200 & 200 & 50 & 10 & 10 \\
\hline $\begin{array}{c}\text { New heat electropower } \\
\text { station (brown coal) }\end{array}$ & 200 & 200 & 50 & 7 & 10 \\
\hline $\begin{array}{c}\text { Mini power plant with } \\
\text { internal-combustion } \\
\text { engine (gasoline) }\end{array}$ & 2 & 250 & 300 & 115 & 5 \\
\hline $\begin{array}{c}\text { Steam-gas plant } \\
\text { (natural gas) }\end{array}$ & 5 & 100 & 100 & 10 & 2 \\
\hline $\begin{array}{c}\text { Electrochemical } \\
\text { generator based on } \\
\text { SOFCs (natural gas) }\end{array}$ & 0 & $>3$ & $>7$ & $>3$ & 0 \\
\hline
\end{tabular}


At present however, the techno-economic potential of this technology faces two main critical issues, i.e. the development of a low cost production process for the cell components and their inadequate durability. The current approach of reducing the SOFC's operation temperature allows for a wider choice of low cost materials, particularly for the interconnection (including metallic) and the sealant, a longer cell life-time due to lessened interdiffusion among stack components, improved reliability and a reduced overall cost. In this regard, the electrolyte materials of choice, those that exhibit high conductivity and sufficient stability, are based on ceria and lanthanum gallate [5-8].

Recently, multicomponent electrolytes based on $\mathrm{CeO}_{2}$ have attracted great interest. It is known that the main disadvantage of ceria-based electrolytes, and this complicates their commercial application, is the appearance of electronic conductivity at low oxygen partial pressures because of $\mathrm{Ce}^{4+}$ being partially reduced to $\mathrm{Ce}^{3+}$. Some effort has been made to suppress the electronic conductivity and to extend the electrolyte domain of the ceria-based electrolytes. Structural modification of ceria-based solid solutions by co-doping is one of the possible ways to enhance their electrical conductivity. The ionic radii of $\mathrm{Ce}^{4+}$ and $\mathrm{Ce}^{3+}$ in $\mathrm{CeO}_{2}$ are 0.97 and $1.14 \AA$, accordingly. It was assumed that the fluorite lattice of $\mathrm{CeO}_{2}$ accepts dopants which have an average ionic radius up to $1.14 \AA$. It was found that if the trivalent rare earth element sites in $\mathrm{CeO}_{2}-\mathrm{Re}_{2} \mathrm{O}_{3}$ solid solutions are further partly substituted by univalent or divalent element, so that the trivalent rare earth element sites are made to have a lower valence, the quantity of oxygen vacancies is increased.

Univalent or divalent elements having an ionic radius larger than $\mathrm{Ce}^{4+}$ expand the lattice and increase the space in the crystal lattice allowing the oxygen ions to pass through. A large quantity of oxygen vacancies not only increases conductivity in air, but also minimizes change to the defective ceria type compound from $\mathrm{Ce}^{4+} \rightarrow \mathrm{Ce}^{3+}$ in reducing atmospheres. Mori et al. showed that

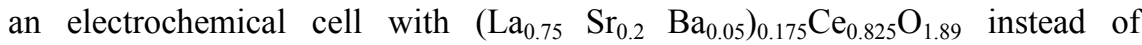
$\mathrm{Sm}_{0.2} \mathrm{Ce}_{0.8} \mathrm{O}_{1.9}$ as its electrolyte had a power density three times higher at the same temperatures [9].

This report describes a number of experimental studies on solid state electrolytes for intermediate temperature SOFCs. Emphasis is given to two important aspects, the effect of different dopants' ionic radius and concentration on the electrical properties of $\mathrm{CeO}_{2}$ based solid solutions and the influence of the method of preparation on the structural properties of ceria ceramics and the electrochemical performance of single SOFCs on their base.

\section{Experimental}

\subsection{The preparation procedure and powder characterization}

The solid-state composition $\mathrm{Ce}_{1-\mathrm{x}} \mathrm{Ln}_{\mathrm{x}} \mathrm{O}_{2-\delta}(\mathrm{Ln}=\mathrm{La}, \mathrm{Nd}, \mathrm{Sm}, \mathrm{Eu}, \mathrm{Gd}$, Dy, Ho, Er, $\mathrm{Yb})$, some multicomponent systems $\mathrm{Ce}_{1-\mathrm{x}} \operatorname{Ln}_{\mathrm{x} / 2} \operatorname{Ln}^{\prime}{ }_{\mathrm{x} / 2} \mathrm{O}_{2-\delta}(\mathrm{x}=0-0.20 ; \mathrm{Ln}=\mathrm{Sm}$, $\mathrm{La}, \mathrm{Gd}$ and $\left.\mathrm{Ln}^{\prime}=\mathrm{Dy}, \mathrm{Nd}, \mathrm{Y}\right)$, some systems with simultaneous doping by rare earth and alkali earth elements $\mathrm{Ce}_{0.8}\left(\mathrm{Sm}_{1-\mathrm{x}} \mathrm{M}_{\mathrm{x}}\right)_{0.2} \mathrm{O}_{2-\delta}(\mathrm{M}=\mathrm{Ca}, \mathrm{Sr} ; \mathrm{x}=0.0-1.0)$ 
and $\mathrm{Ce}_{0.8}\left(\mathrm{Sm}_{1-\mathrm{x}-\mathrm{y}} \mathrm{Ba}_{\mathrm{y}} \mathrm{M}_{\mathrm{x}}\right)_{0.2} \mathrm{O}_{2-\delta} \quad(\mathrm{M}=\mathrm{Ca}, \quad \mathrm{Sr} ; \quad \mathrm{x}=0, \quad 0.15, \quad 0.20$; $\mathrm{y}=0.05,0.1)$ were synthesized by applying three different techniques: solidstate reaction (solid-powders), laser induced evaporation of solid state target (laser-powders) and glycine-nitrate method (chem-powders) (Fig. 1). The temperature of calcinations varied from 600 to $1150^{\circ} \mathrm{C}$ depending on the procedure.

The specific surface area obtained powders were tested by surface area and porosity analyzer TriStar 3000 V6.03 A. The content of metal oxides in the starting materials and solid-state composition, obtained by different methods, was defined by a Plasma Emission Spectrometer Optima 4300DV (USA). The $\mathrm{X}$-ray diffraction (XRD) technique was employed to identify the phases and to obtain the values of the lattice constants.

The XRD analysis was performed on the milled powders of specimens by using a DMAX-2500 (Rigaku Co. Ltd., Japan) diffractometer with Ni-filtered $\mathrm{Cu} \mathrm{K} \mathrm{K}_{\alpha}$ radiation in the range of $10^{\circ} \leq 2 \theta \leq 120^{\circ}$. The crystallite size $d_{x}$ was determined from the broadening of the X-ray diffraction lines according to the Scherer procedure.
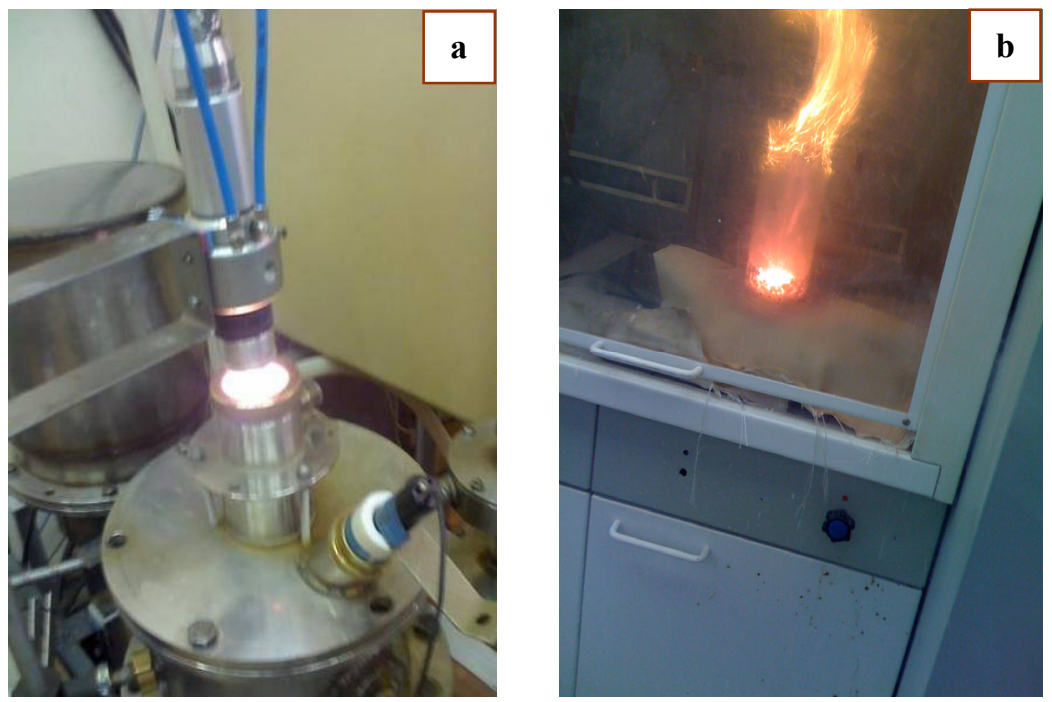

Figure 1: a. Laser induced evaporation of ceramic target, b. combustion route.

\subsection{The preparation and characterization of ceramic samples}

Powders prepared by different procedures were compacted by the magnetic pulse technique in the Institute of Electrophysics UB RAS [10] in $2 \mathrm{~mm}$ thick pellets with a diameter of $30 \mathrm{~mm}$ (pulsed pressure $300 \mathrm{MPa}$ in amplitude and $100 \mathrm{mks}$ in duration) and sintered in air in an electric furnace with controlled heating (heating/cooling rate $5^{\circ} \mathrm{C} / \mathrm{min}$, maximal temperature was $1600^{\circ} \mathrm{C}$ with holding time $3 \mathrm{~h}$ ) (fig. 2b). The dilatometer Dil $402 \mathrm{C}$ was used to investigate the 
sintering dynamics. The densities of the samples were determined by hydrostatic weighing in water. The grain size and its distribution on the surface of sintered ceramic samples were investigated by raster electronic microscope JSM-5500 LV JEOL, Japan.

\subsection{Investigation of electrical properties}

The electrical conductivity measurements of the samples were carried out by employing the four-point dc technique making use of the home-made electrochemical experimental set [11]. The specimens were installed in a tube made from $\mathrm{ZrO}_{2}$-based electrolyte. Platinum paste stripes, which were deposited on the inner and outer surface of the YSZ tube and connected with platinum wires, were used as the electrochemical oxygen pump and the oxygen sensor. Four Pt electrodes were deposited on the samples' surface and connected with Pt wires. Atmospheres with varying oxygen partial pressures inside the tube were created by pumping in oxygen and they were then registered by the sensor.

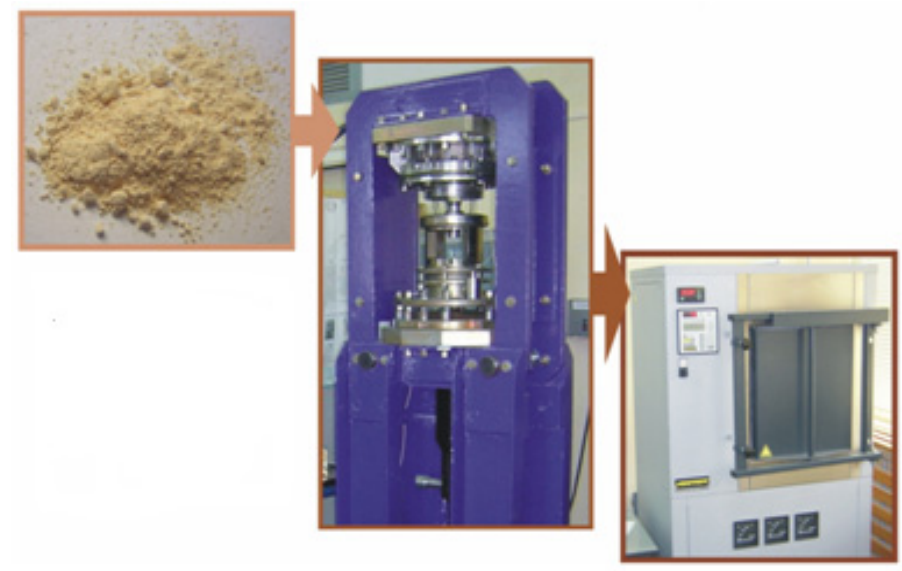

Figure 2: The technology scheme of the ceramic samples preparation. Temperature and oxygen partial pressure were varied automatically by means of a microprocessor system Zirkonia-318 in the range of $350-900^{\circ} \mathrm{C}$ and $0.21-10-24$ atm, respectively.

\section{Results and discussion}

\subsection{Structural properties}

The XRD analysis revealed that all the synthesized $\mathrm{Ce}_{1-\mathrm{x}} \mathrm{Ln}_{\mathrm{x}} \mathrm{O}_{2-\delta}$ and $\mathrm{Ce}_{1-\mathrm{x}} \mathrm{Ln}_{\mathrm{x} / 2} \mathrm{Ln}_{\mathrm{x} / 2}^{\prime} \mathrm{O}_{2-\delta}$ compositions were single phase with a cubic fluorite structure like pure $\mathrm{CeO}_{2}$. The compositions $\mathrm{Ce}_{0.8}\left(\mathrm{Sm}_{1-\mathrm{x}} \mathrm{M}_{\mathrm{x}}\right)_{0.2} \mathrm{O}_{2-\delta}(\mathrm{M}=\mathrm{Ca}, \mathrm{Sr}$; $\mathrm{x}=0.0-1.0$ ) with $\mathrm{Ca}^{2+}$ were single phase throughout the full range of compositions, while the solubility limit of $\mathrm{Sr}^{2+}$ was approximately $8 \mathrm{~mol} . \%$, so at $\mathrm{x}>0.4$ the second phase $\mathrm{SrCeO}_{3}$ was identified. All XRD-patterns of 
the compositions $\mathrm{Ce}_{0.8}\left(\mathrm{Sm}_{1-\mathrm{x}-\mathrm{y}} \mathrm{Ba}_{\mathrm{y}} \mathrm{M}_{\mathrm{x}}\right)_{0.2} \mathrm{O}_{2-\delta}(\mathrm{M}=\mathrm{Ca}, \mathrm{Sr} ; \mathrm{x}=0$, 0.15, 0.20; $\mathrm{y}=0.05,0.1)$ showed a pure cubic structure without any second phases. However the microstructure of these samples as seen by scanning electron microscopy demonstrated the appearance of second phase in the triple points.

The parameters of elementary cells $a$ and crystallite sizes $d_{x}$ of powders were determined from the broadening of the X-ray diffraction lines, an average bulksurface effective diameter of particles $d_{B E T}$ was calculated from specific surface area of powders $S_{B E T}$, which was about $1.5-2,20-25$ and $40-45 \mathrm{~m}^{2} / \mathrm{g}$ for solid, chem and laser-powders, respectively. In the case of Laser-powders there was close concurrence in crystallite size, calculated from XRD-data and $d_{B E T}$, because they were not agglomerated, having mainly spherical shaped particles (SEM image in Fig. 3a and TEM image in Fig 3b). Chem-powders were agglomerated, but the microsized agglomerates were spongy, so the specific surface area increased, more than in the case of Solid-powders, which were strongly
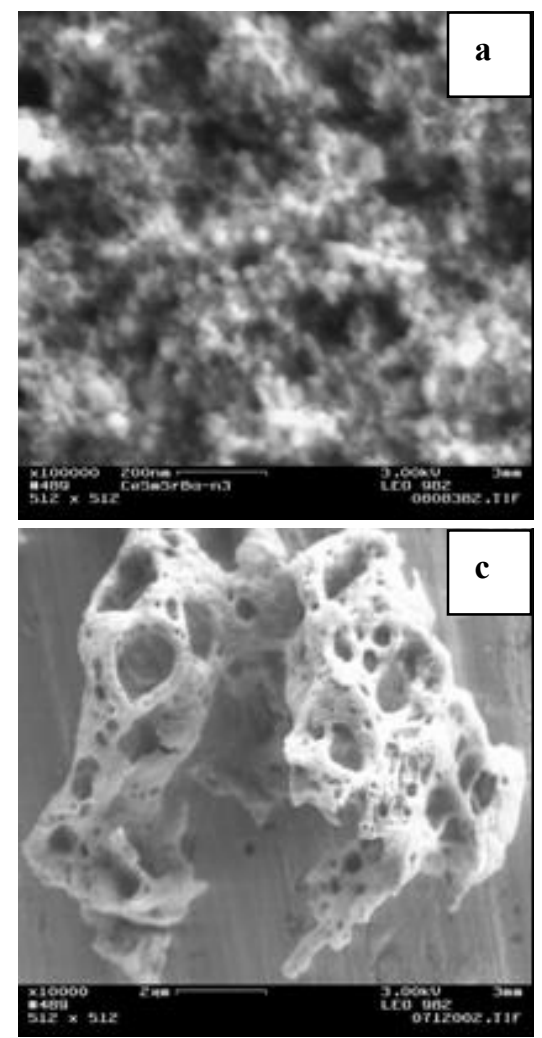
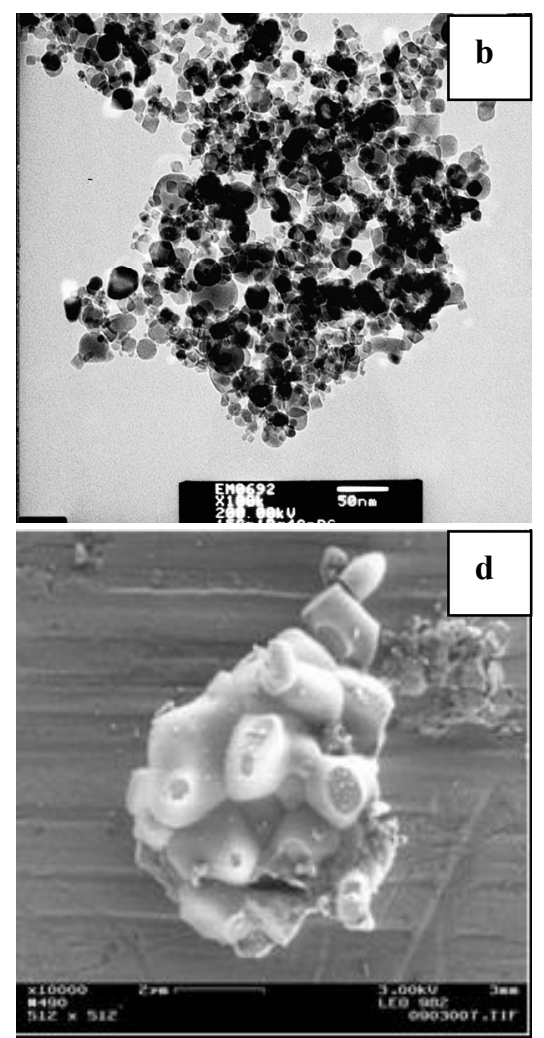

Figure 3: $\quad \mathrm{a}, \mathrm{b}-$ Microstructure of powders prepared by laser induced evaporation, $\mathrm{c}-$ glycine-nitrate combustion and $\mathrm{d}-$ solid state reaction methods. 
agglomerated and the procedure of their milling did not significantly alter the picture for some hours (Fig. 3c and d). The dilatometric investigation of sintering kinetics showed that the optimal sintering temperatures for sample preparation with a relative density of no less than $95 \%$ were 1400 and $1500,1600^{\circ} \mathrm{C}$ for laser, chem and colid-powders, respectively.

\subsection{Electrical properties in air}

The introduction of the dopant cation (regardless of its radius) significantly increases the total electrical conductivity of $\mathrm{CeO}_{2}$. The highest value for electrical conductivity in air was found for $\mathrm{Ce}_{0.8} \mathrm{Nd}_{0.2} \mathrm{O}_{2-\delta}\left(14.8 \times 10^{-2}\right.$ and $13.3 \times 10^{-3} \mathrm{~S} / \mathrm{cm}$, at 900 and $750^{\circ} \mathrm{C}$, respectively). The dependence of electrical conductivity on the effective radius of the dopant passes through a maximum at $\mathrm{r}_{\mathrm{d}}=0.1109 \mathrm{~nm}$. According to the classical theory [12], the minimal distortion in the lattice and consequently the maximum electrical conductivity, corresponds to the cation dopant with a radius of $0.1024 \mathrm{~nm}$ and any further increase in the dopant's radius will compromise the oxygen anion movement of the diffusion paths overlapping by neighboring cations.

Indeed, we obtained the minimal changes in the lattice's parameters in $\mathrm{CeO}_{2}$ doped with $\mathrm{Dy}^{3+}$ with the effective radius of $0.1027 \mathrm{~nm}$, but the electrical conductivity of samples with this dopant was rather low. Therefore, in order to select a suitable dopant it is necessary to take into account not only the size of the cation, but also the formation of local structures such as cation-oxygen vacancy complexes depending on cation-vacancy binding energy values. It was shown on the base of DFT-calculations [13] that $\mathrm{Nd}^{+3}$ and $\mathrm{Sm}^{+3}$ have the minimal values of binding energy in $\mathrm{CeO}_{2}$ lattice and the bulk conductivity of solid solutions based on them are almost equal. For all dopants the conductivity increases with the dopant's concentration excluding $\mathrm{Dy}^{3+}$ and $\mathrm{Eu}^{3+}$, whose maximal value of conductivity was found to be at $\mathrm{x}=0.15\left(8.5 \times 10^{-2}\right.$ and $12.1 \times 10^{-2} \mathrm{~S} / \mathrm{cm}$ at $900^{\circ} \mathrm{C}$, respectively).

Among $\mathrm{Ce}_{1-\mathrm{x}} \mathrm{Ln}_{\mathrm{x} / 2} \mathrm{Ln}^{\prime}{ }_{\mathrm{x} / 2} \mathrm{O}_{2-\delta}$ the highest values of conductivity for $\mathrm{Ce}_{0.8} \mathrm{La}_{0.1} \mathrm{Dy}_{0.1} \mathrm{O}_{2-\delta}$ and $\mathrm{Ce}_{0.8} \mathrm{Nd}_{0.1} \mathrm{Sm}_{0.1} \mathrm{O}_{2-\delta}$ were observed $\left(11.1 \times 10^{-2}\right.$ and $10.0 \times 10^{-2} \mathrm{~S} / \mathrm{cm}$ at $\left.900^{\circ} \mathrm{C}\right)$. The effect of increased conductivity when co-doping $\mathrm{CeO}_{2}$ with two rare earth elements was found only under a low concentration of dopants. As a rule the values of conductivity of the three-component systems were equal to the average value of conductivities of the relevant two-component systems. Throughout the entire concentration range for two-component systems the maximum level of conductivity was found when using $\mathrm{Nd}^{3+}$ as a dopant. These results are similar to those obtained in [14].

Adding the correct amount of alkaline earth elements $\mathrm{Ca}^{2+}$ and $\mathrm{Sr}^{2+}$ (2-4 mol.\%) significantly increases the conductivity of the samples. The same results were found for $\mathrm{Ce}_{0.8}\left(\mathrm{Sm}_{1-\mathrm{x}-\mathrm{y}} \mathrm{Ba}_{\mathrm{y}} \mathrm{M}_{\mathrm{x}}\right)_{0.2} \mathrm{O}_{2-\delta}(\mathrm{M}=\mathrm{Ca}, \mathrm{Sr} ; \mathrm{x}=0,0.15,0.20$; $\mathrm{y}=0.05,0.1)$. It was confirmed by the technique of impedance spectroscopy that $\mathrm{CaO}, \mathrm{SrO}$ and $\mathrm{BaO}$ addition increases the grain boundary conductivity by a magnitude of more than 10 . It should be noted that the conductivity of the samples with $\mathrm{Sr}^{2+}$ is higher due to the lower binding energy of $\mathrm{Sr}-\mathrm{O}(33.4 \mathrm{eV})$ compared to $\mathrm{Ca}-\mathrm{O}(35.44 \mathrm{eV})$. The binding energy of $\mathrm{Ba}-\mathrm{O}$ is minimal among 
the alkaline earth elements $(31.44 \mathrm{eV})$, but due to the fact that the effective radius of $\mathrm{Ba}^{2+}$ is $0.142 \mathrm{~nm}$, and its solubility in the fluorite lattice is less than $2 \mathrm{~mol} . \%$, the number of single-phase solid solutions on the base of $\mathrm{BaO}$ is limited. Nevertheless, it was found that the samples with $\mathrm{Ba}^{2+}$ have the lowest activation energy for total conductivity. The highest value for total conductivity $16.2 \times 10^{-2} \mathrm{~S} / \mathrm{cm}$ at $900{ }^{\circ} \mathrm{C}$ was attributed to $\mathrm{Ce}_{0.8}\left(\mathrm{Sm}_{0.8} \mathrm{Sr}_{0.2}\right)_{0.2} \mathrm{O}_{2-\delta}$. and $\mathrm{Ce}_{0.8}\left(\mathrm{Sm}_{0.75} \mathrm{Sr}_{0.2} \mathrm{Ba}_{0.05}\right)_{0.2} \mathrm{O}_{2-\delta}$.

\subsection{Electrolytic properties}

It is well known that the rate of electrochemical reactions in solid oxide fuel cells is determined by the driving forces of the processes, which, in turn, are determined by the difference between the partial pressure of oxygen in the anode and cathode channels. The greater this difference, the higher is the power output of the electrochemical cell. Usually, with the cathode channel oxygen partial pressure is chosen in the range $0.21^{-1} \mathrm{~atm}$. Problems arise in reducing conditions (anode channel), since at the partial pressure of oxygen below $10^{-15} \mathrm{~atm}$ cerium systems are characterized by the appearance of electronic conductivity due to the partial reduction of $\mathrm{Ce}^{4+} \rightarrow \mathrm{Ce}^{3+}$. The electronic conductivity of solid solutions based on $\mathrm{CeO}_{2}$ is determined by the dopant's radius, its concentration and temperature. Dependence of total conductivity on $P_{O_{2}}^{*}$ was investigated at 750 and $900^{\circ} \mathrm{C}$. To describe the electrolytic properties of solid electrolytes the notation of the EDB (electrolytic domain boundary) - critical oxygen partial pressure $\left(P_{\mathrm{O}_{2}}^{*}\right)$ at which the values of the electronic and ionic components of conductivity are equal, was used. The minimal value of $P_{O_{2}}^{*}$ among $\mathrm{Ce}_{1-\mathrm{x}} \operatorname{Ln}_{\mathrm{x}} \mathrm{O}_{2-\delta}$ solid solutions was found for $\mathrm{Ce}_{0.8} \mathrm{Sm}_{0.2} \mathrm{O}_{2-\delta}$ composition $\left(2.76 \times 10^{-21}\right.$ atm at $750^{\circ} \mathrm{C}$ ). A decrease in the dopant radius results in an increase in $P_{\mathrm{O}_{2}}^{*}$ and a relevant narrowing of the electrolytic region. The minimal electrolytic domain boundary value was found for the composition $\mathrm{Ce}_{0.9} \mathrm{Yb}_{0.1} \mathrm{O}_{2-\delta}\left(4.57 \times 10^{-13} \mathrm{~atm}\right)$. An increase in the dopant concentration and a lowering of temperature leads to a decrease in the critical partial pressure irrespective of the dopant.

Among the three-component systems the lowest values of $P_{O_{2}}^{*}$ equal to $1.16 \times 10^{-18}$ atm was found for $\mathrm{Ce}_{0.8} \mathrm{Nd}_{0.1} \mathrm{Sm}_{0.1} \mathrm{O}_{2-\delta}$. For compositions $\mathrm{Ce}_{0.8}\left(\mathrm{Sm}_{1-\mathrm{x}} \mathrm{M}_{\mathrm{x}}\right)_{0.2} \mathrm{O}_{2-\delta}$ the value of $P_{O_{2}}^{*}$ increases with $\mathrm{CaO}$ content (with $\mathrm{x}=0$; 0.2 and 0.5 are $2.76 \times 10^{-21} ; 5.05 \times 10^{-18} ; 1.31 \times 10^{-18}$ atm, respectively), while $\mathrm{SrO}$ addition decreases it (with $\mathrm{x}=0.2$ and 0.3 are $3.33 \times 10^{-19}$ and $9.88 \times 10^{-23}$ $\mathrm{atm}$ ). The addition of $\mathrm{BaO}$ also leads to expansion of the electrolytic area of codoped systems. The lowest value $3.30 \times 10^{-23}$ atm at $750^{\circ} \mathrm{C}$ was found for $\mathrm{Ce}_{0.8}\left(\mathrm{Sm}_{0.75} \mathrm{Sr}_{0.2} \mathrm{Ba}_{0.05}\right)_{0.2} \mathrm{O}_{2-\delta}$. In some of the investigations by the Mori group $[9,15]$ it was also shown that co-doping with alkali earth elements not only leads to an increase in electrical conductivity of solid electrolytes based on $\mathrm{CeO}_{2}$, but also expands their electrolytic areas. 


\subsection{Electrochemical performance}

Fig. 4 presents the electrochemical characteristics of single SOFCs on the base of $\mathrm{Ce}_{0.8}\left(\mathrm{Sm}_{0.75} \mathrm{Sr}_{0.2} \mathrm{Ba}_{0.05}\right)_{0.2} \mathrm{O}_{2-\delta}$ and traditionally used in IT-SOFCs $\mathrm{Ce}_{0.8} \mathrm{Sm}_{0.2} \mathrm{O}_{1.9}$ ceramic electrolytes made by different methods. The investigation was carried out using an electrolyte supported electrochemical cell $(0.8 \mathrm{~mm}$ of electrolyte thickness) with separated cannels: $\mathrm{H}_{2}+5 \% \mathrm{H}_{2} \mathrm{O}, \mathrm{Pt} / \mathrm{electrolyte} / \mathrm{Pt}$, air.

The electrochemical properties of $\mathrm{Ce}_{0.8} \mathrm{Sm}_{0.2} \mathrm{O}_{1.9}$ are strongly affected by the method of their preparation which can give the samples superior density and their electrical properties. The specific power of a single electrochemical cell based on Solid, Chem, and Laser electrolyte was 80,120 and $130 \mathrm{~mW} / \mathrm{cm}^{2}$ at $750^{\circ} \mathrm{C}$ (with $\mathrm{OCV}$ values, respectively, $0.75,0.79$ and $0.80 \mathrm{~V}$ ).

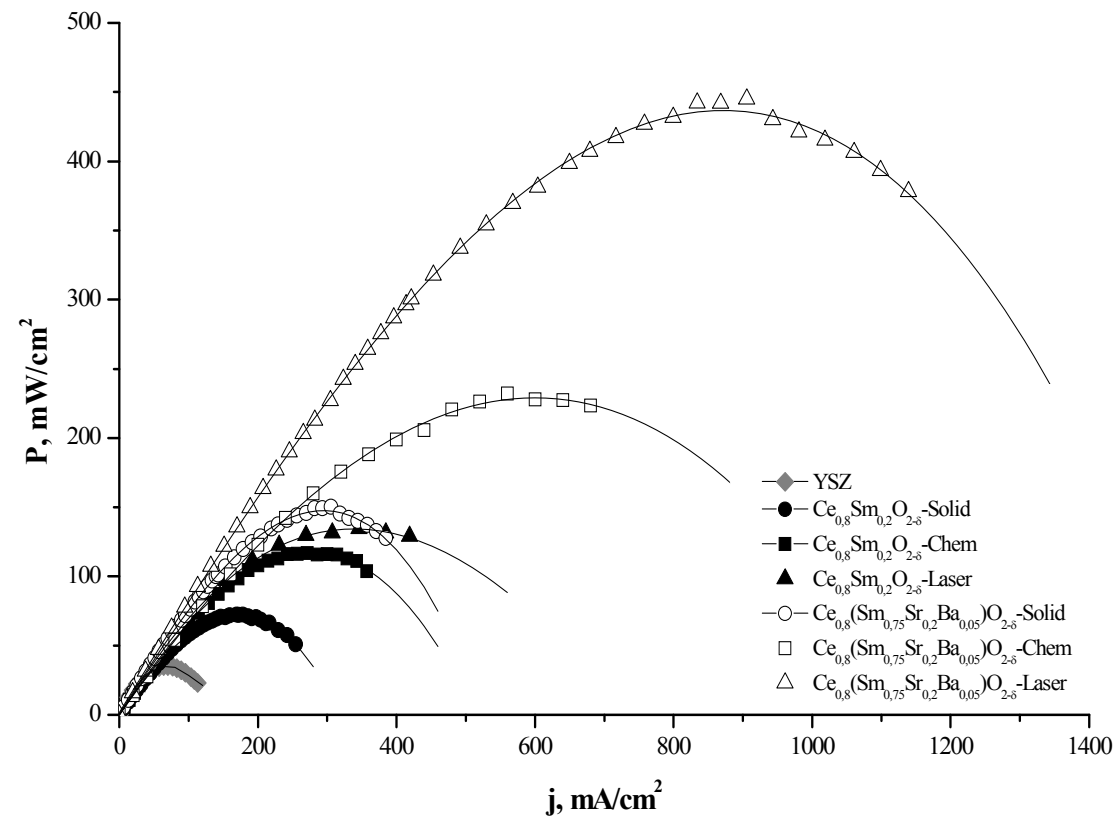

Figure 4: Electrochemical performance (specific power) of single SOFCs with supported electrolyte $(0.8 \mathrm{~mm})$ made by different methods, measured at $750^{\circ} \mathrm{C}$ with fuel $\mathrm{H}_{2}+5 \% \mathrm{H}_{2} \mathrm{O}$.

It was found that an introduction of $\mathrm{Sr}^{2+}$ and $\mathrm{Ba}^{2+}$ significantly improved not only the structural and electrical, but also the electrochemical properties of the $\mathrm{CeO}_{2}-\mathrm{Sm}_{2} \mathrm{O}_{3}$ electrolyte. The best characteristics were found in the $\left(\mathrm{Sm}_{0.75} \mathrm{Sr}_{0.2} \mathrm{Ba}_{0.05}\right)_{0.2} \mathrm{Ce}_{0.8} \mathrm{O}_{2-\delta}$ electrolyte, prepared by the method of laser evaporation of ceramic target. The specific power of a single SOFC on this base reached $450 \mathrm{~mW} / \mathrm{cm}^{2}$ at $750^{\circ} \mathrm{C}$ (with OCV values of $0.95 \mathrm{~V}$ ). Compared to the traditional high temperature SOFC electrolyte $8 \% \mathrm{Y}_{2} \mathrm{O}_{3}-\mathrm{ZrO}_{2}$ (the samples were 
made from electrolyte elements fabricated by Chepetsk engineering works) it is approximately 9 times higher.

More information about $\mathrm{CeO}_{2}$ based electrolytes, their structural and electrical properties and their high temperature application was presented in [16].

\section{Conclusions}

The effect of the cation radius of the dopant and its concentration on the physicochemical properties of solid solutions $\mathrm{Ce}_{1-\mathrm{x}} \operatorname{Ln}_{\mathrm{x}} \mathrm{O}_{2-\delta}$ $(\mathrm{x}=0-0.20 ; \mathrm{Ln}=\mathrm{La}, \mathrm{Nd}, \mathrm{Sm}, \mathrm{Eu}, \mathrm{Gd}, \mathrm{Dy}, \mathrm{Ho}, \mathrm{Er}, \mathrm{Yb})$ were investigated. It was found that across the whole concentration range compositions with $\mathrm{Nd}^{3+}$ possess the highest values of conductivity at high temperatures, while at low temperatures (below $600^{\circ} \mathrm{C}$ ) - those with $\mathrm{Sm}^{3+}$ do. The investigation of multi-component systems $\mathrm{Ce}_{1-\mathrm{x}} \mathrm{Ln}_{\mathrm{x} / 2} \mathrm{Ln}^{\prime}{ }_{\mathrm{x} / 2} \mathrm{O}_{2-\delta}(\mathrm{x}=0-0.20 ; \mathrm{Ln}=\mathrm{Sm}, \mathrm{La}, \mathrm{Gd}$ and $\left.\mathrm{Ln}^{\prime}=\mathrm{Dy}, \mathrm{Nd}, \mathrm{Y}\right), \mathrm{Ce}_{0.8}\left(\mathrm{Sm}_{1-\mathrm{x}} \mathrm{M}_{\mathrm{x}}\right)_{0.2} \mathrm{O}_{2-\delta}$ and $\mathrm{Ce}_{0.8}\left(\mathrm{Sm}_{1-\mathrm{x}-\mathrm{y}} \mathrm{Ba}_{\mathrm{y}} \mathrm{M}_{\mathrm{x}}\right)_{0.2} \mathrm{O}_{2-\delta}$ $(\mathrm{M}=\mathrm{Cs}, \mathrm{Sr})$ showed that increased conductivity is observed only with the addition of alkaline earth elements.

The highest value for total conductivity $16.62 \times 10^{-2} \mathrm{~S} / \mathrm{cm}$ at $900^{\circ} \mathrm{C}$ was obtained for $\mathrm{Ce}_{0.8}\left(\mathrm{Sm}_{0.8} \mathrm{Sr}_{0.2}\right)_{0.2} \mathrm{O}_{2-\delta}$. It was shown that co-doping with $\mathrm{SrO}$ and $\mathrm{BaO}$ not only leads to increased electrical conductivity for solid electrolytes based on $\mathrm{CeO}_{2}$, but also expands their electrolytic area. The lowest value $3.30 \times$ $10^{-23}$ atm of the critical oxygen partial pressure $P_{O_{2}}^{*}$ at which the values of the electronic and ionic components of conductivity are equal was found for $\mathrm{Ce}_{0.8}\left(\mathrm{Sm}_{0.75} \mathrm{Sr}_{0.2} \mathrm{Ba}_{0.05}\right)_{0.2} \mathrm{O}_{2-\delta}$. The electrochemical properties of electrolytes are strongly affected by the method of preparation which can give superior density of samples and their electrical properties. The specific power of a single electrochemical cell based on $\mathrm{Ce}_{0.8} \mathrm{Sm}_{0.2} \mathrm{O}_{1.9}$ made by solid state reaction, nitrate combustion and laser evaporation methods was 80,120 and $130 \mathrm{~mW} / \mathrm{cm}^{2}$ at $750^{\circ} \mathrm{C}$ (with $\mathrm{OCV}$ values, respectively, $0.75,0.79$ and $0.80 \mathrm{~V}$ ). It was found that an introduction of $\mathrm{Sr}^{2+}$ and $\mathrm{Ba}^{2+}$ significantly improves not only the structural and electrical, but also the electrochemical properties of $\mathrm{CeO}_{2}-\mathrm{Sm}_{2} \mathrm{O}_{3}$ electrolyte. The best characteristics were found for $\left(\mathrm{Sm}_{0.75} \mathrm{Sr}_{0.2} \mathrm{Ba}_{0.05}\right)_{0.2} \mathrm{Ce}_{0.8} \mathrm{O}_{2-\delta}$ electrolyte, prepared by the method of laser evaporation of ceramic target. The specific power of a single SOFC on this base reached $450 \mathrm{~mW} / \mathrm{cm}^{2}$ at $750^{\circ} \mathrm{C}$ (with OCV values of $0.95 \mathrm{~V}$ ). These materials can be recommended for use in intermediate temperature electrochemical devises including SOFCs. Our future investigations will be concentrated on the development of electrode supported cells with thin film $\mathrm{CeO}_{2}$ based electrolyte.

\section{Acknowledgements}

The present work was financially supported Russian Foundation for Basic Research and Government of Sverdlovsk Region (grant № 13-03-96098) and in frame of Program № 12-T-3-1003 of Chemistry and Material Science Division of RAS. 


\section{References}

[1] European Commission, Green Paper - Towards an European Strategy for the Security of supply, 2001.

[2] Energy Strategy of Russia until 2030, Moscow, GU IES, 2010.

[3] Russian Energy: A View to the Future (Substantiating materials of The Energy Strategy of Russia for the period up to 2030), Moscow, GU IES, 2010.

[4] European Commission's communication "Energy 2020 - A strategy for competitive, sustainable and secure energy", 2010.

[5] Antonucci, V., Antonucci, P.L., Gullo, L., La Rosa, D. \& Siracusano, S., Advanced (electro) ceramics and innovative energy technologies. Journal of European Ceramic Society, 24, pp. 1337-1342, 2004.

[6] Pikalova, E.Yu., Bamburov, V.G., Murashkina, A.A., Neuimin, A.D., Demin, A.K. \& Plaksin, S.V., Solid Electrolytes based on $\mathrm{CeO}_{2}$ for Medium-Temperature Electrochemical Devices. Russian Journal of Electrochemistry, 47(6), pp. 690-696, 2011.

[7] Ilhan, Z., Ansar, A. \& Soysal, D., Recent progress in intermediate temperature SOFCs (ITSOFCs) Development at DLR, Institute of Electrochemistry and Energy Systems. Advances and innovations in SOFCs. From materials to systems, pp. 30-36, 2011.

[8] Nesaraj, A.S., Recent developments in solid oxide fuel cell technologies a review, Journal of Scientific and Industrial Research, 69, pp. 169-176, 2010.

[9] Mori, T., Drennan, J., Wang, Y., Li, J.-G. \& Ikegami T., Journal of Thermal Analysis and Calorimetry, 70, pp. 309-319, 2002.

[10] Ivanov, V.V., Paranin S.N. \& Vikhrev A.N., Method of Pulsed Pressing of Solid Powder Materials and the Setup for its Implementation, Patent RU 2083328 C1, April 25, 1996.

[11] Pikalova, E. Yu., Maragou, V.I., Demina, A.N., Demin, A.K., Tsiakaras, P.E., The effect of co-dopant addition on the properties of $\mathrm{Ln}_{0.2} \mathrm{Ce}_{0.8} \mathrm{O}_{2-\delta}$ ( $\mathrm{Ln}=\mathrm{Gd}, \mathrm{Sm}, \mathrm{La})$ solid-state electrolyte, Journal of Power Sources, 181, pp. 199-206, 2008.

[12] Kim, D.-J., Lattice Parameters. Ionic Conductivities. and Solubility Limits in Fluorite-Structure $\mathrm{MO}_{2}$ Oxide $\left(\mathrm{M}=\mathrm{Hf}^{4+} \cdot \mathrm{Zr}^{4+} \cdot \mathrm{Ce}^{4+} . \mathrm{Th}^{4+} \cdot \mathrm{U}^{4+}\right)$ Solid Solutions, Journal of American Ceramic Society, 72, pp. 1415-1421, 1989.

[13] Andersson, D., From the Electronic Structure of Point Defects to Functional Properties of Metals and Ceramics: Doctoral Thesis, Royal Institute of Technology (Sweden), Stockholm, 2007.

[14] Yahiro, H., Eguchi K. \& Arai H., Electrical properties and reducibility of ceria-rare earth oxide systems and their application to solid oxide fuel cell, Solid State Ionics, 36, pp. 71-75, 1989.

[15] Omar, S., Wachsman, E. D. \& Nino, J. C., A co-doping approach towards enhanced ionic conductivity in fluorite-based electrolytes, Solid State Ionics, 177, pp. 3199-3203, 2006. 
272 Energy Production and Management in the 21st Century, Vol. 1

[16] T. Mori \& H. Yamamura, Preparation of an Alkali-Element or AlkaliEarth-Element-Doped $\mathrm{CeO}_{2}-\mathrm{Sm}_{2} \mathrm{O}_{3}$ System and Its Operation Properties as the Electrolyte in Planar Solid Oxide Fuel Cells, Journal of Materials Synthesis and Processing, 6, pp. 175-179, 1998.

[17] Pikalova, E.Yu., $\mathrm{CeO}_{2}$ based solid solutions: synthesis, physico-chemical properties, application in high temperature electrochemistry monograph, [in Russian], LAP LAMBERT Academic Publishing GmbH\& Co: Saarbrücken, Germany, 2012. 